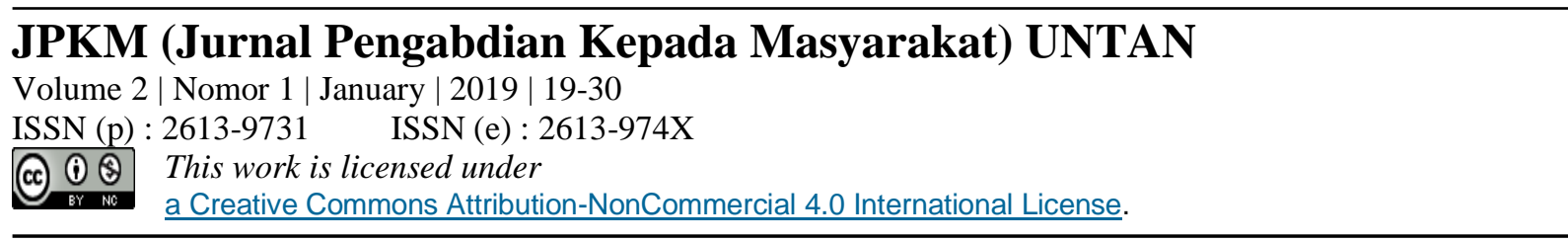

\title{
Teachers' Effort to Implement Cultural Education and National Character Values through PPKn in Senior High School
}

\author{
Hamid Darmadi \\ IKIP PGRI Pontianak, Pontianak, Indonesia
}

Email: hamiddarmadi@gmail.com

\section{Keywords :}

Teacher Efforts, Cultural

Education, Nation Character Values
ABSTRACT
This study is titled: Teacher's Efforts to Implement Cultural Education and National Character Values Through Learning West Kalimantan State High School Bengkayang PPKn. The problem in this study is "How Teachers' Efforts to Implement Cultural Education and Nation Character Values Through Learning PPKn in Bengkayang State High School, West Kalimantan Province. This study aims to" obtain objective information and clarity regarding the Implementation of Character Education through learning PPKn in the Learning Process in Bengkayang State High School. This research is reviewed from two benefits, namely theoretical and practical benefits. The population in this study were students and teachers of Bengkayang State High School PPKn. Data collection was carried out using direct communication techniques using a questionnaire as a data collection tool, indirect communication techniques using interview guides to school principals, teachers, and students who were designated as informants. Besides these two tools, observation techniques and documentation techniques are also used. Data processing uses non-metric descriptive statistical techniques with 1) the formula "Percentage" to find out the percentage of success of the PPKn teacher Applying cultural education and national character values. 2) the "Mean" formula to find the average number of school success rates. Implement cultural education and national character values from the School Indicators, Class Indicators, and Student Behavior Indicators. 3) Standard Deviation (SD) formula to find out the highest and lowest levels of each school applying cultural education and national character values. 4) Absorption formula to determine the level of absorption of each school using each School Indicator effect, Class Indicator, and Student Behavior Indicator. The results of this study show that Teachers' Efforts to Implement Cultural Education and Nation Character Values Through Learning PPKn in Bengkayang State High School are in the "Fair" position. The actual score is 90,139, and the ideal score is 182,532, with a percentage level of $49.38 \%$. It is recommended that the Bengkayang State High School 


\begin{abstract}
Authority instruct the School Principals and PPKn teachers so that in providing learning material they are not in a hurry to get into the subject matter, but instead start the lesson first by instilling Character Education. The Regional Government, through the Office of Education and Culture, needs to collaborate with the School authorities to improve the implementation of Cultural Education and National Character Values in PPKn learning.
\end{abstract}

\title{
INTRODUCTION
}

Character Education is one of the issues that is very widely discussed in the perspective of curriculum implementation, including in the current 2013 curriculum. Discussing the issue of Character Education is not without a strong psychological reason considering the moral damage to this nation not only occurs among the Government bureaucracy, law enforcement circles, and adults but also has propagated to the nation's moral damage as a whole starting from elementary school-age children. Up to the effect of all national and state life.

The spread of moral violations is now not only spread in various layers of society but has entered into multiple institutions, including educational institutions. Even institutions that are trusted by this country to enforce laws such as the Constitutional Court (MK) make moral and legal violations even worse. Moral and legal violations occur in various types of wildlife, ranging from OTT by the KPK, free sex, abuse/authority/power, buying and selling certificates, diplomas, Phone Ques fraud, narcotics, pornography, and pornographic action, underage sexuality, mass cheats, domestic violence, misuse of seminars to countless fields. Should we leave the moral depravity of this nation without our will and good intentions to improve the character of this nation's children? The answer is in each child of this nation. For more than 68 years, we have been free, which should be free from morality and law, but the reality shows that the situation is contrary to the teachings of the National Character Education. Moral depravity and lawlessness occur in almost all lines of community, nation, and state life.

According to the writer's observation, one of the causes of the nation's moral depravity is the "weak implementation of character education in schools." Application of Character Education is not like medicine that is swallowed instantly healed, but it requires a long process of time. Character education can improve and prevent conditions, as mentioned above, and is considered capable of restoring the image of a nation that was once known as a friendly nation. It is as stated by; Joseph Zink et al. (2001) in a book entitled Emotional Intelligence, and School Success states that: The purpose of character education is to instill values in learners and renewal of shared life that respects individual freedom. The long-term goal is to familiarize yourself with the individual's contextual active responses to social, natural impulses encountered in daily life, which in turn further sharpens the vision of life that will be achieved through the process of self-formation continuously. This long-term goal is a dialectical approach that is increasingly closer to the ideal reality, through a process of reflection and continuous interaction between idealism, choice of means, and direct results that can be evaluated objectively.

Character Education also aims to improve the quality of implementation and educational outcomes in schools that lead to the achievement of the formation of character and noble character for students as a whole, integrated, and balanced in accordance with the graduation competency standards embedded in the 2013 curriculum. Through character education, students are expected to be able to independently improve and use their knowledge, study and internalize and personalize the values of character and noble character and the attitude that is commendable so that it is manifested in the behavior of everyday life.

Constitutionally, character education, at the institutional level, leads to the formation of school culture, the values that underlie behavior, traditions, daily habits, and symbols practiced by all school 
members both within the school environment and towards the surrounding community. School culture is a characteristic, character or character, and the image of the school in the eyes of the wider community. This noble goal of character education will have a direct impact on the cognitive, affective, and psycho-psychological achievement of students, which is the goal of applying the 2013 curriculum. According to Suyanto (2002), several studies mention the positive impact of character education implementation on academic success for a student.

Joseph Zink et al. (2001), in a book titled "Emotional Intelligence and School Success," compiles various research results about the positive influence of students' emotional intelligence on success in school. According to Joseph Zink et al. (2001) that many factors cause student failure at school. These factors do not lie in the intelligence of one's brain, but rather lie in character, namely self-confidence, the ability to work together, the ability to get along, the ability to concentrate, a sense of empathy, and the ability to communicate.

The concept of Joseph Zink et al. (2001) turned out to be supported by Daniel Goleman's opinion about the success of one's career in society. According to Daniel Goleman, $80 \%$ of one's career success in the community is influenced by emotional intelligence, and only $20 \%$ is determined by brain intelligence (IQ). Children who have problems with emotional intelligence will have difficulty learning, socializing, and cannot control their emotions. Children who have problems can be seen from preschool age, and if not treated quickly, will carry over into adulthood. Conversely, adolescents with character will avoid common problems faced by adolescents such as drugs, drugs, alcohol, free sex, and so on.

Some countries that have implemented character education from an early age starting from primary education include the United States, Japan, China, and Korea. The results of research in these countries indicate that the systematic implementation of character education has a positive impact on the academic achievement of students. Minister of Education and Culture of the Republic of Indonesia Message from the Minister of Education and Culture in Commemoration of the 2013 National Teacher's Day and PGRI's 68th Birthday Monday, November 25, 2013, in Jakarta, said;

We want our children to be wherever they are and whatever their social and economic backgrounds can get the highest possible educational services. Education must be affordable and of good quality. Teachers and education personnel are the determining factors so that we inevitably have to increase their availability and professionalism.

The Government, through the Ministry of Education and National Culture Since 2010, has launched the application of Character Education for all levels of education, from elementary schools to tertiary institutions. This program was launched, not without reason. Because, all this time, the world of education is considered to be less successful in delivering the young generation in the hope of the nation to become individuals who have strong, characterless characters. The world of education is considered only capable of giving birth to human graduates with an adequate level of intellect. Many of the school graduates have high grades (although there is a tendency for some grades to be obtained in an impure way), intelligent, brilliant, and able to solve various subjects very precisely. Unfortunately, not a few of them are intelligent people who don't have intelligent behavior and brilliant attitudes and lack a good mental personality, as academic values that have been achieved in school or college.

The above phenomenon raises concerns for many people. What would happen if this country has a lot of smart people, but it turns out mental and behavior are not smart at all. There is no correlation between the high value obtained in the education bench with their behavior in the midst of community life. As a result, came the figures of smart people who use fools or intelligent people who oppress the weak. In fact, in essence, education is carried out not just to pursue values, but to give direction to everyone so that they can act and behave appropriately in accordance with the principles and spirit of learning.

The achievement of these principles is very closely related to the task of teachers as educators. Because, educating is an activity of giving teaching to students, making it able to understand something, and with the understanding it has, it can develop its potential by applying something that it has learned. 
If there is a backward look in the context of the nationhood of Indonesia, there are many Educational Objectives that have colored the educational goals in this country. Among the educational objectives are as follows:

1. Law Number 12 of 1954 concerning the Application of Law of the Republic of Indonesia Number 4 of 1950 concerning the Basics of Education and Teaching in Schools for all of Indonesia. Article 9 Says: Therefore, in education and teaching in the Republic of Indonesia, national priority is given in the sense that education and teaching are based on our own culture. In such an education, the teaching of history will be essential for teaching. Various events that occur in our history must be reviewed, by bridging our sources, so that Indonesian history books can be compiled, which are different from when viewed with the eyes of a foreign nation. Events that can be proud of and show the glory of our nation must be clearly stated to create a sense of confidence in our youth. Likewise, the teaching of art, both art and dance, and so on. And the more important thing, which expresses the true nature of national education in our country, is that the Indonesian language is the language of instruction in all schools. Language is a tool for thinking and a tool for expressing the fruit of thought, but apart from all that is the most essential tool to strengthen the national sense of a nation. Although the principle that the language of instruction in schools is Indonesian is compromised based on psychology, thus, that in the lowest third class of low schools, the language of instruction is regional languages.

2. Law Number 2. of 1989 states that: Education aims to educate the life of the nation and develop a complete human being, that is, people who believe in and fear God Almighty and are virtuous, possessing knowledge and skills, physical and spiritual health, a steady and independent personality, and a sense of community and national responsibility.

3. The National Education System Law No.20 of 2003 states that; National education functions to develop capabilities and shape the dignified character and civilization of the nation in the context of developing the intellectual life of the nation, aiming at improving the potential of students to become human beings who believe in and fear God Almighty, have noble, healthy, knowledgeable, capable, creative, independent, and be a democratic and responsible citizen.

4. The National Education Objectives state that; The aim of National Education is education based on the Pancasila and the 1945 Constitution of the Republic of Indonesia, which is rooted in religious values, Indonesian national culture, and responsive to the demands of changing times.

5. National Education based on Pancasila and the 1945 Constitution of the Republic of Indonesia. National Education functions to develop capabilities and shape the character and civilization of a dignified nation in the context of developing the intellectual life of the nation.

The purpose of education can give us a brief description that education is carried out not only to give birth to intelligent generations but, at the same time, a virtuous, noble generation, which is a reflection of intelligence itself. It's just that the problem is our hope to have a nation generation that is not only intelligent but also has a noble character who seems to face many obstacles that need a solution.

\section{METHOD}

\section{A. Research Design}

This research is "Descriptive Research." Descriptive research is one type of research whose aim is to present a complete picture of social settings or relationships between the phenomena tested. In this study, researchers already have a clear definition of the subject of research and will use the question in exploring the information needed. Namely "Teacher's Efforts to Implement Cultural Education and National Character Values in the Learning Process in Bengkayang Regency State High School The purpose of descriptive research is to reveal events and phenomena on the ground as they exist to produce an accurate picture of a group, describe the mechanism of a process or relationship, provides a complete picture either in verbal or numerical form, presents basic information about a relationship, creates a set of categories and classifies research subjects, explains a set of stages or processes, and to store contradictory information about the research subject. Events and phenomena in the field as they are. At this stage, the researcher collaborates with the Principal and the Teacher Council to determine the steps of the study. 


\section{B. Research Implementation}

At this stage the researchers entered into a cooperation contract and collaborated with the School Principal and the Teacher Council to determine the steps and timetable for the willingness of Bengkayang Regency High School schools to accept the arrival of the research team going to the field (to Bengkayang Regency High School) as follows:

a. Conducting visits to state high schools in Bengkayang Regency to monitor learning activities Implementation of Character Education in the Learning Process in Schools in accordance with a predetermined schedule

b. Distribute and reassemble data collection tools in the form of questionnaires in the form of attitude scales that originate from the effect of character values in the form; school indicators, class indicators and student indicators that are in accordance with the objectives of the Implementation of Character Education in the Learning Process in Schools that have been designed in such a way as to State High Schools in the Landak District which are the object of research

c. Conducting observations to observe the activities of teachers implementing Character Education in the Learning Process in State High Schools in Landak District to check the truth of the Implementation of Character Education in the Learning Process to State High Schools in Bengkayang Regency which are the object of research to preserve the value -Pasasila values and the 1945 Constitution.

d. Monitor Character Education implementation activities to state high schools in Landak Regency to find out what activities have been, are being and will be carried out by teacher-students in implementing Character Education in the Learning Process in Schools in accordance with the predetermined schedule ( This activity is more focused on teacher-student activities outside the classroom)

e. Observe the activities of implementing Character Education to State High Schools in Landak Regency to find out what activities have been, are, and will be carried out by teacher-students in implementing Character Education in the Learning Process in Schools according to the schedule determined (This activity is more focused on teacher-student learning activities in the classroom)

f. Observe the availability, suitability, accuracy of tools and media used by teachers to implement Character Education in Efforts to Implement Cultural Education and Nation Character Values in the Learning Process in Bengkayang Regency State High School to preserve the values of Pancasila and the 1945 Constitution.

C. Time and Place of Research

This research was conducted in the State Senior High Schools in Bengkayang Regency from March to Bengkayang 2015. The schools which were the place of research were the Landak District State Senior High Schools, which were reached by 15 researchers.

\section{Population and Research Samples}

The population as the subject of this research is the Principal, Deputy Principal, Subject Subject Teachers, and a number of students who are determined in quota as research samples. The teacher population of 15 Bengkayang Regency High Schools in this study was 338 teachers, a sample of 287 teachers, and a sample of 70 students.

\section{E. Research Data Collection Techniques and Tools}

To collect data in this study used several techniques and data collection tools commonly used in research in general. The techniques of collecting data are 1) indirect communication techniques with questionnaire tools; 2) direct communication techniques with the tool interview guides; 3) direct observation techniques with the observation guide tool; 4) documentation techniques with tools in the form of information records, school principal and teacher data copies, school student data copies, photographing/videotaping school buildings, school nameplates, school situations, school offices, student activities inside and outside the classroom in implementation character building. The documentation activities are carried out with the Sony R model camcorders No.DCR-SX20E series; 1735791 and Sony R model No.DCR-SR68E 3786100 and HP series. Nokia E75; HP. Samsung 
Galaxy S4; Nokia E72, BlackBerry Mobile Samsung Galaxy Tab, and a number of Handycam and other cellphones.

Indirect communication techniques with the tool were in the form of a questionnaire; addressed to School Principals, subject matter teachers including Guidance and Counseling teachers (for those with a counseling teacher), as well as many students who are the object of research for each Hedgehog State High School.

Direct communication techniques with the tool in the form of interview guides were conducted with Principals, subject matter teachers, including Guidance and Counseling teachers (for those with a BK teacher), as well as many students used as research objects for each Hedgehog State High School. Direct observation technique with the tool observation guide is done by; observe the activities of the teacher directly teaching students learning, directly observing the activities of students doing extra-curricular activities such as scouting activities; flag ceremony training; create a school park; making a school garden; clean the classroom; make/write on the creative board of students and others.

The documentation technique with its tools in the form of a collection of school records and documents is done by taking notes, digging information, copying school data, among others: Principal and teacher data, copying data of school students, photographing/videotaping school buildings, school name boards, school situations, school offices, student activities inside and outside the classroom as a manifestation of the implementation of Cultural Education and Nation Character Values in the Learning Process in Schools. Data obtained using questionnaire instruments, interviews, observations, and documentation are processed with the stages of the preparation activities as follows:

a. Make a questionnaire instrument in the form of an attitude scale. Attitude Scale is made based on eighteen (18) character values effects (Ministry of National Education 2011) consisting of 1) School Indicators, 2) Class indicators, and 3) Indicators of Student Behavior Make interview guides. The interview guide was developed from eighteen (18) effects of character values (adapted from the Ministry of National Education Research and Development Center 2010 Curriculum Center), which includes: 1) School Indicators, 2) Class indicators and 3) Indicators of Student Behavior.

b. Make an interview guide. The interview guide is intended as a guide tool for interviewers in conducting interviews, both interviews with the Principal and interviews with teachers and students who are used as research objects

c. Make an observation guide. The observation guide is used as a guide for observers when observing in each school to see the activities of each school in implementing Character Values Education, and when conducting classroom observations to see the teacher's teaching activities in implementing Character Values Education in class.

d. Gather documentation data. : School documentation data collected in the form of; The existence of the school building, the situation of the school, the data of the Principal and the teachers supporting the subjects, the student data, the physical data of the school building structure, and the data of school infrastructure facilities owned by each Bengkayang State High School. The next activity is to monitor, record the activities of students inside and outside the classroom as a form of the realization of the implementation of Cultural Education and National Character Values in the Learning Process in Schools.

F. Data Analysis Techniques and Tools

To analyze the data collected in this study, the research team conducted:

a. The data collected by the researcher is sorted/separated according to the quality of the data to be verified and then processed both quantitatively and qualitatively.

b. Data collected through a questionnaire in the form of an attitude scale is entered in the tabulation of data to be then processed statistically

c. Quantitative data collected through a questionnaire about the implementation of Cultural Education and National Character Values in the Learning Process in Schools through the character values affect consists of School Indicators, Class Indicators, and Student Behavior Indicators processed using the percentage formula.

d. Qualitative data collected through interviews, observations, and documentation about the implementation of Cultural Education and Nation Character Values in the Learning Process in Schools through character aspect values consisting of School Indicators, Class Indicators, and 
Student Behavior Indicators processed in form description of the results of the interview, description of the results of observations and description of the results of the collection of documentation data in accordance with the nature and type of data collected.

\section{RESULTS AND DISCUSSIONS}

A. Description of Teacher Questionnaire Interpretation

The description of the results of the questionnaire interpretation of the teacher's attitude scale on the application of character education by the teacher in the learning process in Landak State High School is in the position of the actual score of 90,139 from the ideal score of 182,532 or $49.38 \%$ including the category of "Enough" This means that the State High School teachers Hedgehogs have sought the implementation of Cultural Education and national character values in the learning process at the School. Although not all items of character education values measured can be implemented, Landak High School has tried to implement them. It means that teachers' efforts to implement "Cultural Education and Nation Value of the Nation" must still be increased. Thomas Lickona (1985) says, "The Nightmare of Loosing: You lose your wealth, you lose nothing. You lose your health, and you lose something. You lose your character, and you lose everything ".

1. School Indicators.

Efforts by teachers to implement Cultural Education and national character values in the learning process in Bengkayang State High School through school indicators are in the position of an actual score of 33,886 from an ideal score of 68,880 or $49.20 \%$ t included in the category of "Enough."

2. Class Indicators

Teachers' efforts to implement character values through class indicators in the learning process at school are at an actual score of 26,738 from an ideal score of 53,956 or $49.56 \%$ including the "enough" category, meaning that Hedgehog State High Schools have implemented character values through indicators class in the learning process.

3. Student Behavior Indicators.

Teachers' Efforts to Implement Character Values through Student Behavior Indicators have an actual score of 29,515 out of an ideal score of 59,696, or $49.44 \%$ including the "enough" category, meaning that school teachers have implemented character values in the learning process at school.

B. Description of Percentage of Implementation of Student Questionnaire Character Education

Description of the Percentage of Character Education Implementation in the Learning Process in Schools Based on Each Aspect and Research Indicators (Based on Student Questionnaire).

1. School Indicators

Efforts by teachers to implement Cultural Education and national character values in the learning process at Hedgehog State High Schools through school indicators based on students' perceptions are in the actual score position of 8,143 from an ideal score of 16,800 or $48.47 \% \mathrm{t}$ included in the category of "Enough."

2. Class Indicators.

The teacher's effort to implement character values through classroom indicators in the learning process at the school is at an actual score of 6,668 from an ideal score of 13,160 or $49.14 \%$ including the "sufficient" category, and this means that the Landak High School has implemented character values through classroom indicators in the learning process.

3. Student Behavior Indicators

Teachers' Efforts to Implement Character Values through Student Behavior Indicators have an actual score of 7,098 from an ideal score of 14,560 or $48.75 \%$, including the category of "sufficient," This means that school teachers have implemented character values in the learning process at school. Furthermore, the acquisition of data from the variable effect of the character values of each research indicator, namely: School Indicators, Class Indicators, and Student Behavior Indicators included in the calculation of absorption analysis as follows.

C. Absorption Implementation of Cultural Education and Values of National Characters Based on Aspects of School Indicators.

To find out how much the absorption of each indicator of the Implementation of Cultural Education and Nation Character Values in the Learning Process in Bengkayang Regency State High School, a 
book is used: "Jakarta Kemendikbud 1995 Learning Assessment System".

1. Absorption Based on Aspects of School Indicators

Absorption Implementation of Cultural Education and Character Values in the Learning Process in Landak District State Senior High Schools. Based on the School Indicator Aspect, the following formula is used:

2. Interpretation of Absorption Based on Aspects of School Indicators

School Effect Indicator. Teachers' Efforts to Implement Cultural Education and National Character Values in the Learning Process in Landak State High School are 8,143 from the maximum score of 16,800 with the absorption of $48.47 \%$. It means that the success of Landak High School students absorbing character values through School Indicators in the learning process in schools is in the category of "Enough."

D. Absorption Based on Aspects of Class Indicators.

To find out how much the absorption of each indicator of the Implementation of Cultural Education and the Nation's Character Values in the Learning Process in Landak District State Senior High Schools, a book is used: "Jakarta Kemendikbud 1995 Learning Assessment System".

E. Absorption Based on Aspects of Class Indicators

Absorption Implementation of Cultural Education and Character Values in the Learning Process in Landak District Public High Schools.

F. Absorption Based on Aspects of Class Indicators

Class Indicator. The teacher's effort to implement character values through classroom indicators in the learning process at school is at a score of 6,468 from a maximum score of 13,160 with an absorptive capacity of $49.15 \%$. It means that the success of Landak High School students absorbing character values through class indicators in the learning process is in the sufficient category.

G. Absorption Aspect of Student Behavior Indicators

To find out how much the absorption of each indicator of the Implementation of Cultural Education and the Nation's Character Values in the Learning Process in Landak District Public High Schools is used the book: "Jakarta Kemendikbud 1995 Learning Assessment System".

H. Absorption Based on Aspects of Student Behavior Indicators

Absorption Power of Implementation of Cultural Education and Character Values in the Learning Process in Landak District Public High Schools.

I. Interpretation of the Absorption Indicator of Student Behavior

Student Indicators. Teacher's Efforts to Implement Cultural Education and National Character Values in the Learning Process in Landak State High School are in the acquisition score of 7,097 from a maximum score of 14,560 with the absorption of $48.75 \%$. It means that the success of Hedgehog High School students absorbing character values through Student Indicators in the learning process is in the "Enough" category.

\section{A. Conclusions}

\section{CONCLUSION AND SUGGESTION}

Based on the analysis of data on the Application of Cultural Education and Values of National Character Learning Process in Schools which are expressed through 18 items of character values that are manifested in School Indicators, Class Indicators and Indicators of Students, it can be concluded in general that: "Application of Character Education in the Process Learning in Schools through Teachers' Efforts to Implement Cultural Education and National Character Values in the Learning Process in Landak District Public High Schools is in the "Fair" position, with an actual score of 90,139, and an ideal score of 182,532 with a percentage level of $49.38 \%$ which means that the Implementation of Character Education in the Learning Process in Hedgehog State High Schools through Teacher Efforts to Implement Cultural Education and Nation Character Values in the Learning Process in the State High School Bengkayang Regency is only in the "Fair" position.

B. Suggestions

Based on the results of quantitative and qualitative data analysis on "Teachers' Efforts to Implement Cultural Education and National Character Values in the Learning Process in Landak District Public High Schools" through; Aspect of character values which include: School Indicators, Class Indicators, and Student Behavior Indicators, it is necessary to recommend the following,

1. It is hoped that the authority of Landak Public High School should emphasize all subject 
teachers in providing learning material, not only delivering the content but also prioritizing learning strategies that prioritize character building of students, because through Cultural Education and Values Nation Character Value is expected that students will be able to independently improve and use their knowledge, study and internalize and personalize the values of character and noble character so that it is manifested in their daily life behavior.

2. It is expected that Landak High School authorities should emphasize the students (students) graduates who have faith and devotion to God Almighty, have good morality, academic competence intact and integrated, and have a good personality in accordance with norms and culture Indonesian nation. At a broader level, it is expected that school authorities emphasize to students (students) that Cultural Education and National Character Values will later be expected to become a school culture that is imprinted up to life behavior in the family, community, nation, and state.

3. It is hoped that the Regional Government authorities through the Department of Education and Culture can collaborate with the School authorities to be able to work together to improve the implementation of Cultural Education and National Character Values in the Learning Process in schools, so there is no mutual blame and the creation of a command.

4. It is expected that the Regional Government authorities and the authorized officials need to strive for teachers to be happy without coercion but with their awareness willing to implement Cultural Education and National Character Values through all subjects in each Learning Process in Schools by providing " Reward and Punishment "for teachers who excel in instilling Cultural Education and National Character Values in schools

5. Local Government Authorities and School Authorities Need to program upgrading or training activities for all subject teachers so that Cultural Education and National Character Values that they (teachers) instill to students on target (not deviating) from the concept of the Act Education Number 20 Year 2003 and 2013 Curriculum by inviting "Education Specialists" from Education Personnel Education Institutions (LPTK) such as from IKIP or FKIP as well as from other relevant institutions that are competent for it.

6. Local Government Authorities and School Authorities Need to provide adequate school facilities to support the implementation of Cultural Education and National Character Values in accordance with the concepts of Pancasila Education and the 1945 Constitution

7. Local Government Authorities and School Authorities Need to hold/promote School Principal Work Group (KKKS) Activities and Subject Teachers' Consultation (MGMP) to increase cooperation between schools and, to "Share" opinions to complement and complement each other about how is the best way to implement Culture Education and National Character Values learning in the Learning Process in schools

8. The School Authority, in collaboration with the School Committee, needs to hold a place of worship, facilities for prayer, and celebrate religious holidays in school in accordance with the established Education Calendar, providing facilities for finding lost items. Make school reports transparently and periodically, providing an honesty canteen with the support of the school committee. Provide suggestions and complaints boxes for school residents and have school operational instructions for expressing dissatisfaction for students.

9. The School Authority and the Teacher Council need to conduct a scheduled, sub-summative, and summative assessment of learning outcomes. Give equal treatment to all school members regardless of ethnicity, religion, race, class, social status, economic status, and special abilities, give appreciation to school members who are disciplined and outstanding, have the discipline of students, teachers, and school employees, enforce rules by giving fair sanctions to violators of school rules, Creating a healthy atmosphere of competition in schools. Creating a challenging school atmosphere and encouraging students to work hard and not easily give up.

\section{REFERENCES}

Albertus, Doni Koesoema (2007) Pendidikan Karakter: Strategi Mendidik Anak di Zaman Global, Jakarta: PT. Grasindo,

Ali, Muhammad (1998), Penelitian Kependidikan: Prosedur dan Strategi, Bandung: Angkasa. 
Anggoro, Toha, M dan Andriani Durri (2007) Metode Penelitian. Jakarta: Universitas Terbuka.

Arikunto, S., (1998) Prosedur Penelitian Suatu Pendekatan Praktek, Jakarta: Rineka Cipta

Dewan Pendidikan Provinsi Kalimantan Barat (2010) Grand Desain Pendidikan Karakter, Makalah hasil Seminar Para Tokoh Masyarakat, Perguruan Tinggi Dewan Pendidikan dan LSM Kalbar

Darmadi Hamid (2007) Dasar Konsep Pendidikan Moral (DKPM) Dasar Konsep dan Implementasi Bandung, Alfabetha;

Darmadi Hamid (2008) Pendidikan Pancasila Dasar Konsep dan Implementasi Bandung, Alfabetha

Darmadi Hamid (2010) Pengantar Pendidikan Kewarganegaraan, Dasar Konsep dan Implementasi Bandung, Alfabetha ; 2010

Darmadi Hamid (2014) Metode Penelitian Pendidikan, Dasar Konsep dan Implementasi Bandung, Alfabetha

Djajendra (2012) http://edukasi.kompasiana.com/2012/10/18/ pengem- bangan- karakter-kebangsaanindonesia-502523.htm

Djamarah, S.B. (2000) Guru dan Anak Didik Dalam Interaksi Edukatif. Jakarta: PT. Rineka Cipta.

Hasballah M. Saad, (2003) Perkelahian Pelajar; Potret Peserta didik SMU di DKI Jakarta (Yogyakarta; Galang Press), hlm. 97.

http://akhmadsudrajat.wordpress.com/2010/12/04/definisi-pendidikan-definisi-pendidikan-menurutuu-no-20-tahun-2003-tentang-sisdiknas $\wedge$ di akses pada tanggal 15 November 2012

http://dikdas.kemdiknas.go.id/application/media/file/PP\%20No_17\%20Tahun\%202010\%20ttg\%20PE NGELOLAAN\%20DAN\%20PENYELENGGARAAN\%20PENDIDIKAN.pdf di akses pada tanggal 17 November 2012

http://ftp.unm.ac.id/permendiknas-2006/Nomor\%2022\%20Tahun\%202006.pdf di akses pada tanggal 17 November 2012

http://hukum.unsrat.ac.id/men/permendiknas 39 2008.pdf di akses pada tanggal 17 November 2012

http://juprimalino.blogspot.com/2012/04/tujuan-pendidikan-karakter-dan-karakter.html. di akses pada tanggal 17 November 2012

http://lugtyasyonos3ip.staff.fkip.uns.ac.id/files/2011/12/1.-pp-no-19-tahun-2005-tentang-snp.pdf di akses pada tanggal 17 November 2012

http://ulfiarahmi.wordpress.com/2010/12/20/pendidikan-karakter-dalam-uu-no-20-tahun-2003/ di akses pada tanggal 15 November 2012

http://www.dikti.go.id/files/atur/UU20-2003Sisdiknas.pdf. di akses pada tanggal 17 November 2012 http://www.inherent-dikti.net/files/sisdiknas.pdf di akses pada tanggal 15 November 2012

http://118.98.166.62/application/media/file/Policy\%20Brief\%20Edisi\%204.pdf di akses pada tanggal 15 November 2012

Instruksi Presiden Republik Indonesia Nomor 1 Tahun 2010 tentang Percepatan Pelaksanaan Pembangunan Nasional Tahun 2010.

James W. Popham dan Kenneth A.Siratnik. (1973). Education Statistics: use and interpretation, Harper and publisher, New York.

Kartadinata, S. Mencari Bentuk Pendidikan Karakter Bangsa. Artikel dalam website Universitas Pendidikan Indonesia.

Kementerian Pendidikan Nasional (2003), Undang-Undang Republik Indonesia Nomor 20 Tahun 2003 tentang Sistem Pendidikan Nasional.

Kementerian Pendidikan Nasional (2005) Peraturan Pemerintah Republik Indonesia Nomor 19 Tahun 2005 tentang Standar Nasional Pendidikan.

Kementerian Pendidikan Nasional (2006) Peraturan Menteri Pendidikan Nasional Republik Indonesia Nomor 22 Tahun 2006 tentang Standar Isi.

Kementerian Pendidikan Nasional (2006) Peraturan Menteri Pendidikan Nasional Republik Indonesia Nomor 23 Tahun 2006 tentang Standar Kompetensi Lulusan.

Kementerian Pendidikan Nasional (2007) Peraturan Menteri Pendidikan Nasional Republik Indonesia Nomor 19 Tahun 2007 tentang Standar Proses.

Kementerian Pendidikan Nasional (2007) Peraturan Menteri Pendidikan Nasional Nomor 20 Tahun 2007 tentang Standar Penilaian Pendidikan.

Kementerian Pendidikan Nasional (2007) Peraturan Menteri Pendidikan Nasional Republik Indonesia Nomor 41 Tahun 2007 tentang Standar Pengelolaan. 
Kementerian Pendidikan Nasional (2007), Undang-Undang Republik Indonesia Nomor 17 Tahun 2007 tentang Rencana Pembangunan Jangka Panjang Nasional Tahun 2005 - 2025.

Kementerian Pendidikan Nasional (2008) Peraturan Menteri Pendidikan Nasional Nomor 39 Tahun 2008 tentang Pembinaan Kesiswaan.

Kementerian Pendidikan Nasional Suksmo, C.R.P. (2009) Pedoman Pendidikan Akhlak Mulia Siswa SMA. Jakarta: Direktorat Jenderal Manajemen Pendidikan Dasar dan Menengah, Departemen Pendidikan Nasional, 2009.

Kemendiknas (2009) Kebijakan Nasional Pendidikan Karakter Bangsa, Jakarta: Puskur Litbang Kemendiknas.

Kementerian Pendidikan Nasional (2010) Suyanto, Urgensi Pendidikan Karakter Bangsa. Artikel dalam website Kementerian Pendidikan Nasional www.kemdiknas.go.id

Kementerian Pendidikan Nasional (2010) Suyanto, Suyatno, Peran Pendidikan Sebagai Modal Utama Membangun Karakter Bangsa. Makalah disampaikan dalam Sarasehan Nasional "Pengembangan Budaya dan Karakter Bangsa" oleh Kopertis Wilayah 3 DKI Jakarta, 12 April 2010.

Kementerian Pendidikan Nasional (2010) Pengembangan Pendidikan Budaya dan Karakter Bangsa. Badan Penelitian dan pengem-bangan Pusat Kurikulum. Pedoman Sekolah

Kemendiknas Puskur Balitbang, (2010). Pembinaan Budi Pekerti Untuk Sekolah Menengah Atas. Jakarta: Direktorat Pembinaan Sekolah Menengah. Direktorat Jenderal Pendidikan Dasar dan Menengah.

Kemendiknas Puskur Balitbang, (2010). Pembinaan Karakter Bangsa untuk Sekolah Menengah Atas. Jakarta: Direktorat Pembinaan Sekolah Menengah Atas, Direktotar Jenderal Pendidikan Menengah.

Kemendiknas Puskur Balitbang, (2010). Pengembangan Pendidikan Budaya dan Karakter Bangsa:Bahan Pelatihan Penguatan Metodologi Pembelajaran Berdasarkan Nilai-Nilai Budaya Untuk Membentuk Daya Saing dan Karakter Bangsa. Jakarta.

Kementerian Pendidikan Nasional (2010) Grand Desain Pendidikan Karakter, 2010. Jakarta

Kemendiknas Puskur Balitbang, (2011). Pembinaan Karakter Bangsa untuk Sekolah Menengah Atas. Jakarta: Direktorat Pembinaan Sekolah Menengah Atas, Direktotar Jenderal Pendidikan Menengah.

Lickhona, T, E.Shaps, \& C.Lewis. (1995) Eleven principles of effective character education. Washington, DC: Character Education Partnership, 1995. (Dalam website CEP: www.character.org)

Mazzola, J.W. Bullying in schools: a strategic solution (2007). Washington, DC: Character Education Partnership. (Dalam website CEP: www.character.org)

M.Berkowitz \& M.Bier. What works in character education, 2006. Washington, DC: Character Education Partnership. (Dalam website: www.characterandcitizenship.org)

Menteri Pendidikan dan Kebudayaan Republik Indonesia Sambutan Menteri Pendidikan dan Kebudayaan Dalam Peringatan Hari Guru Nasional 2013 dan Ulang Tahun ke-68 PGRI Senin 25 November 2013

Munir, Abdullah, 2010. Pendidikan Karakter: Membangun Karakter Anak Sejak Dari Rumah, Yogyakarta: Pedagogia

Neuman, W. Laurence. (2013) Metodologi Penelitian Sosial: Pendekatan Kualitatif dan Kuantitatif (Social Research Methods: Qualitative and Quantitative Approaches, 7th edition), Jakarta: PT. Indeks. (Bahasa Inggris, Boston: Pearson Education, Inc., Publishing as Allyn \& Bacon (Imprint of Pearson).

Ngalim Purwanto (2004:105)kategorinya berdasarkan tolok ukur, sebagaimana yang dikemukakan M. sebagai berikut

Neuman, W. Laurence. (2013) Metodologi Penelitian Sosial: Pendekatan Kualitatif dan Kuantitatif (Social Research Methods: Qualitative and Quantitative Approaches, 7th edition), Jakarta: PT. Indeks. (Bahasa Inggris, Boston: Pearson Education, Inc., Publishing as Allyn \& Bacon (Imprint of Pearson).

Purwanto, Ngalim, M. (2004). Teknik Evaluasi Pendidikan. Bandung: Tarsito.

Rencana Strategis Kementerian Pendidikan Nasional Tahun 2010-2014. 
Sahrudin. 2011. Tujuan dan Fungsi Media Pendidikan (Online). http://www.sriudin.com/2011/07/tujuan-fungsi-dan-mediapendidikan.html. diakses Senin, 28 Mei 2012. Pukul 21.00 WIB.

Sugiyono (2009). Statistik untuk Pendidikan. Bandung: Alfabeta.

Suyanto. (2010). Panduan Pendidikan Karakter di Sekolah Menengah Pertama. Jakarta: DIKTI

Ventola. (2012). Tujuan dan Fungsi Pendidikan. (Online).. diakses Senin, 28 Mei 2012. Pukul 21.05 WIB 